\title{
A Webometric study of selected academic libraries in eastern and southern Africa using a link analysis approach
}

\author{
Omwoyo Bosire Onyancha' \\ University of Zululand, Private Bag X100I Kwadlangezwa, South Africa \\ b_onyancha@yahoo.com
}

Received: $15^{\text {th }}$ November 2006

Accepted:22 $22^{\text {nd }}$ January 2007

\begin{abstract}
This paper investigates the Web presence and performance of academic libraries drawn from six countries in eastern and southern Africa (i.e. three each from eastern and southern Africa). Using link and content analyses, the study evaluated the libraries' websites in order to: examine the location of the libraries' websites in the university website; measure each library's link performance in terms of web page, directory, domain and site out-links and in-links; examine each library's performance in terms of the provision of essential online services (e.g. web-catalogues, web forms, web search engines, etc.); map the libraries' inter-linkages with each other; and to find out the most targeted web-sites/pages. Results, discussions and recommendations are provided.
\end{abstract}

Keywords: Academic libraries, Eastern Africa, Southern Africa, Link analysis, Webometrics

\section{Introduction}

Worldwide, library practices are undergoing major revolutionary changes courtesy of the emergence of the Internet. Librarians can now perform several tasks through the Internet. Some of these applications include (a) Electronic Mail ( $E$ mail), which librarians can use to communicate with colleagues and other clients and participate in discussion groups where they can share experiences and ideas with other librarians and create and monitor discussion groups of interest to their patrons; (b) Telnet, through which librarians can connect to remote computer resources and explore other library catalogues, access database services, and share resources; and (c) File Transfer Protocol (FTP) which librarians can use to obtain software programs, text images and sound files on their and their clients' behalf (McKenna, 1994). Several authors have noted the opportunities that the Internet offers librarians and libraries (Ahmed, 2002; McKenna, 1994). McKenna (1994) outlines several of these opportunities and benefits which libraries and librarians can enjoy when connected to the Internet thus: leadership opportunities (leadership in the introduction of Internet services to the industry and community, and user training); cost and time savings; question answering services; international interlibrary loans; document delivery services; online transactions; provision of government information; and information sharing.

Libraries in Sub-Saharan Africa have embraced the Internet quite recently and as such they are still struggling to measure up to the Internet-related challenges such as the construction and development of library websites, subscription to online resources (journals, databases, e-books, etc.), implementing their Online Public Access Catalogs (OPAC) sometimes referred to as Webcatalogs - online communication (with patrons, suppliers, etc.), online library acquisitions, library networking (interlibrary loans), etc. All these services require online connectivity on the part of libraries and thus library websites are increasingly becoming, most importantly, a pre-requisite for libraries to offer and market their services online. Partnerships or consortiums, too, among libraries, and between libraries and other institutions, through the Internet are deemed necessary for effective management of their services. The realization of the Internet-related benefits and opportunities, therefore, depends not only on a library's connectivity to the Internet but its Web presence, structure and impact. It thus becomes crucial to audit the libraries' websites periodically with a view to measuring their web presence, structure and impact.

\section{Purpose}

This study sought to audit and map selected university libraries' websites in order to measure the libraries' web structures, content, and visibility/presence. In view of this, the study's focus areas included the following: the number of web pages, in-links, out-links, location of library links on universities' websites, and the most popular link(s) targeted by these universities. The most popular sites were examined with a view to determining the institutions/organizations/sites with which these libraries are linked and/or partner.

I. Omwoyo Bosire Onyancha works as a Deputy Librarian at the University of Eastern Africa, Baraton, P.O. Box 2500, ELDORET Kenya 


\section{Objectives}

The study's objectives include the following:

I.To examine the location of the libraries' websites in the university website.

2.To measure each library's link performance in terms of web page, directory, domain and site out-links and in-links.

3.To examine each library's performance in terms of the provision of essential online services (e.g. webcatalog, web forms, web search engines, etc).

4.To map the libraries' inter-linkages with each other.

5.To find out the most targeted web-sites/pages.

\section{Literature review}

Historically, the Internet and Web are relatively new concepts, but they have elicited a lot of excitement and interest from several scholars as illustrated in the enormous literature that discusses their features, opportunities, challenges and impact, among other issues. Attempts have been made to develop indicators that can be used to measure research and evaluate the performance of individuals, institutions, and countries in the Internet, as a whole and more particularly, on the Web. Virtually all disciplines, including library and information science (LIS), have utilized these Internet-related studies. Specifically, the Internet's (including Web's) impact on libraries and the usage of the Internet-related services by libraries have received attention from several researchers based in various countries and from a variety of disciplines, including LIS

Henry (1996) provides a description of WebCATS - a directory of online public access catalogs that offers access to OPACs which have Web interfaces. A similar description is offered by Kochtanek, Hein \& Kassim (200I) concerning what the authors call 'Projec DL'. The project was meant to create a site that can assist users to access digital library collections as well as information resources related to the study of digital libraries. McCready's (1997) study offers a variety of hints on creating a 'library-related' website. The study focused on the need for a library website, the personnel to develop the website, evaluating its usage, and organizing and structuring it. Westman (200I), too, provides librarians with resources (i.e. database-backed web pages) that they can use for effective construction of library websites. Falk (1999) argues that a library webpage is supposed to serve two purposes, namely provide a means to users to access remotely available information from the library while serving as a patron's guide to the library's collections, and also as a gateway to the resources of the Web. Saeed, Asghar, Anwar \& Ramzan (2000) sought to survey the use of the Internet in university libraries of Pakistan. The authors found that university libraries in Pakistan use the Internet for reference work, classification and cataloguing, document delivery services, and subscription to online journals, etc. On their part, the Arabian Gulf libraries use the Internet to offer such services as web catalogs, web forms, orientation and training and web search engines (Ahmed, 2002). Arte (2001:93) studied the role of the research library website in the management of the scientific information environment and argues that "each library can develop an individualized change management program that takes into consideration the basic elements of experienced staff, new staff, and creative supervisory practices". Several studies have been carried out in order to introduce main ideas and concepts underlying web services, and resources and opportunities that the Internet offer libraries and librarians (e.g. Cordeiro \& de Carvalho, 2002; Hundie, 2003); and library website maintenance (Kennedy, 2004).

There are several indicators or criteria that can be used to evaluate libraries' websites for quality, some of which include design and structure; quality of information; links and navigation; aesthetic impression; miscellaneous; and general assessment (Clausen, 1999). According to Clausen (1999:83), "one of the most serious and widespread objections against information found on the World Wide Web is that the quality in many cases is doubtful". Using the aforementioned criteria for evaluating Danish academic libraries, the author noted that the libraries' websites were above average when compared with other web sites in general. However, they did not measure up to expectations as "virtual expressions of the quality levels of the libraries" (Clausen 1999:83). On her part, Xue (2004) used user statistics to assess the Government Publications Library at the University of Colorado, Colorado, USA. She examined the library website's organization (including access, searchability, and structure) of electronic government information in subject category format and noted, among other issues, that the website attracted a large volume of traffic due to its comprehensive coverage of federal and state government, foreign country and international organizations; detailed classification of subjects; and detailed annotation for each link. She concludes that usage statistics are useful monitoring search engine ranking, improving display, structure and searchability. Pacios (2003) sought to examine management-related documents posted on the Spanish libraries' websites and in view of that the author analyzed the structure and contents of the web pages, among other aspects. Pacios (2003:536) observed that the "information is scanty in many cases - often resulting from a lack of a suitable information policy for determining what is published on the Web - although libraries are beginning to evaluate the quality of their services". 
Director of Mpumalanga's provincial library service estimates, for example, that his rural province needs another 98 public libraries if it is to meet UNESCO guidelines on access (Le Roux \& Hendrikz 2003).

Moreover, the author's research suggests that unavailability is not the only problem. Her survey of Mpaumalanga libraries in 2004 (Hart 2006a; 2006b) shows that township libraries are heavily used by school learners in the afternoons but adults hardly enter them in their quiet mornings. Le Roux (2001: 194) attributes the prevailing under-use to perceptions that the library is for an elite middleclass. In his recent conceptual article on the role of public libraries in good governance (2006), Arko-Cobbah suggests that South African public libraries need to change their image if they wish to extend their services to previously excluded group. It seems that research is urgently needed in how South Africans perceive public libraries.

Witbooi's account of a failed attempt to set up a community/school library in a newly built township in Cape Town gives a rare insight into such perceptions and exemplifies the risk in post 1994 South Africa of too glib assumptions about what she calls an "African" library model (2006). Despite months of preparatory work, the library did not open owing to, it seems, inadequate stocks of trust to sustain the community project beyond early enthusiasm. The case study serves to illustrate many of the points made in the social capital research literature. Only on reflecting on the lessons of the project does Witbooi turn to the concept of social capital in acknowledging that its stocks should have been assessed before the project began. The "chicken and egg" question, referred to earlier, is evident in that the failure was due to the low reserves of social capital in the newly established community; yet, one of the aims of the project was to generate a sense of belonging and community. All in all, the case study offers a tantalising glimpse of how the library might have built social and human capital.

Witbooi attributes the ultimate failure of the project to its unrealistic reliance on volunteers - no professional staff being allocated to the library either by the school system or the local government library authority. And there is evidence that the biggest challenge for new vision-building is the inadequate staffing of South African public libraries - in terms of numbers and quality. The author's 2004 study in Mpumalanga (Hart 2005) found that only $30 \%$ of staff in charge of public libraries have post school education, usually a degree or diploma in librarianship. Twenty-three of the 57 respondents run small rural or township one-person libraries. Of the 23 , only three have post school education - and five lack school leaving matric. These five were promoted from cleaning posts having being deemed to "know it all" after their years of working in the library. The study also reveals a trend to ad-hoc secondments from municipality offices. Local authorities, apparently, have little respect for professional library education.

The issue of professional education is not confined to South African public librarianship. In examining the "crisis" of "disorganized and unproductive" rural libraries in the United States, Luchs (200I: 5I) contends that the prevailing low level of professional education of their staff is their biggest weakness. While acknowledging that the American rural librarians in their studies are dedicated and enthusiastic, both Luchs (200I) and Vavrek (1997) believe that the diverse information needs of their communities demand professionally qualified staff. Luchs's answer to claims that the undereducated staff in her study might be perfectly adequate is that they "simply do not know any better" (200I: 53). Their rural communities, she contends, moreover, may not realise that their library services are inadequate because they have nothing to compare them with. Bundy's warning (2003) that the lack of professional staff in rural Australian libraries hinders leadership and vision is germane to the theme of this article.

Hillenbrand's study of social capital in an Australian public library, which was described in the previous section, demonstrates the importance of ties with other community groups. The author's survey of Mpumalanga libraries suggests, however, that South African public libraries' ties with other community organisations are rather weak. Figure I summarises responses from the 57 respondents to the question on connections with other organisations in the community.

The most common category of partnership is business - a closer look at the responses showing that they all refer to the financial support given to public libraries in Mpumalanga by SAPPI, SASOL and Eskom, three large corporations.

In a country with high levels of adult illiteracy, the absence of any mention of connections to adult literacy groups is surprising and throws doubt on any expectation that South African public libraries might be active in literacy education. Support for this doubt is provided by other recent research that finds that only $23 \%$ of libraries play a role in adult basic education (Nassimbeni \& May 2006: 19). The study reveals, moreover, large variations in the kind of involvement, with some of the $23 \%$ merely offering a venue for literacy education and others directly involved in the programme. The value of the study is that it provides examples of good practice and insight into the favourable conditions that encourage such community work. Perhaps South African librarians need to heed Stambaugh's suggestion that the best way to document the social role of public libraries is through case study research. 


\section{Objectives}

The study's objectives include the following:

I.To examine the location of the libraries' websites in the university website.

2. To measure each library's link performance in terms of web page, directory, domain and site out-links and in-links.

3.To examine each library's performance in terms of the provision of essential online services (e.g. webcatalog, web forms, web search engines, etc).

4. To map the libraries' inter-linkages with each other.

5. To find out the most targeted web-sites/pages.

\section{Literature review}

Historically, the Internet and Web are relatively new concepts, but they have elicited a lot of excitement and interest from several scholars as illustrated in the enormous literature that discusses their features, opportunities, challenges and impact, among other issues. Attempts have been made to develop indicators that can be used to measure research and evaluate the performance of individuals, institutions, and countries in the Internet, as a whole and more particularly, on the Web. Virtually all disciplines, including library and information science (LIS), have utilized these Internet-related studies. Specifically, the Internet's (including Web's) impact on libraries and the usage of the Internet-related services by libraries have received attention from several researchers based in various countries and from a variety of disciplines, including LIS

Henry (1996) provides a description of WebCATS - a directory of online public access catalogs that offers access to OPACs which have Web interfaces. A similar description is offered by Kochtanek, Hein \& Kassim (200I) concerning what the authors call 'Projec DL'. The project was meant to create a site that can assist users to access digital library collections as well as information resources related to the study of digital libraries. McCready's (1997) study offers a variety of hints on creating a 'library-related' website. The study focused on the need for a library website, the personnel to develop the website, evaluating its usage, and organizing and structuring it. Westman (200I), too, provides librarians with resources (i.e. database-backed web pages) that they can use for effective construction of library websites. Falk (1999) argues that a library webpage is supposed to serve two purposes, namely provide a means to users to access remotely available information from the library while serving as a patron's guide to the library's collections, and also as a gateway to the resources of the Web. Saeed, Asghar, Anwar \& Ramzan (2000) sought to survey the use of the Internet in university libraries of Pakistan. The authors found that university libraries in Pakistan use the Internet for reference work, classification and cataloguing, document delivery services, and subscription to online journals, etc. On their part, the Arabian Gulf libraries use the Internet to offer such services as web catalogs, web forms, orientation and training and web search engines (Ahmed, 2002). Arte (2001:93) studied the role of the research library website in the management of the scientific information environment and argues that "each library can develop an individualized change management program that takes into consideration the basic elements of experienced staff, new staff, and creative supervisory practices". Several studies have been carried out in order to introduce main ideas and concepts underlying web services, and resources and opportunities that the Internet offer libraries and librarians (e.g. Cordeiro \& de Carvalho, 2002; Hundie, 2003); and library website maintenance (Kennedy, 2004).

There are several indicators or criteria that can be used to evaluate libraries' websites for quality, some of which include design and structure; quality of information; links and navigation; aesthetic impression; miscellaneous; and general assessment (Clausen, 1999). According to Clausen (1999:83), "one of the most serious and widespread objections against information found on the World Wide Web is that the quality in many cases is doubtful". Using the aforementioned criteria for evaluating Danish academic libraries, the author noted that the libraries' websites were above average when compared with other web sites in general. However, they did not measure up to expectations as "virtual expressions of the quality levels of the libraries" (Clausen 1999:83). On her part, Xue (2004) used user statistics to assess the Government Publications Library at the University of Colorado, Colorado, USA. She examined the library website's organization (including access, searchability, and structure) of electronic government information in subject category format and noted, among other issues, that the website attracted a large volume of traffic due to its comprehensive coverage of federal and state government, foreign country and international organizations; detailed classification of subjects; and detailed annotation for each link. She concludes that usage statistics are useful monitoring search engine ranking, improving display, structure and searchability. Pacios (2003) sought to examine management-related documents posted on the Spanish libraries' websites and in view of that the author analyzed the structure and contents of the web pages, among other aspects. Pacios (2003:536) observed that the "information is scanty in many cases - often resulting from a lack of a suitable information policy for determining what is published on the Web - although libraries are beginning to evaluate the quality of their services". 
It is notable from this brief review of the literature that little has been achieved in evaluating libraries using link analysis. Link analysis is a measure of the quality of and relevance of the set of links pointing to a given site (www.2020visible.com/re-terminology.html). This analysis is meant to assist in determining websites that do promote a given website and how popular one's website is. Link popularity measures how many other sites indexed in the same search engine have links to one's site by count of links to that particular site. This method has been used to measure the universities' web impact factors (Thelwall, 2002a); find the most important university web pages (Thelwall, 2003); identify link relationships between universities (Thelwall, 2002b; 2002c); classify link types in academic environments on the Web (Bar-llan, 2005); and to rank universities (InterLab, 2005).

\section{Methods and tools}

The following procedures were used to identify academic libraries whose websites were the subject of the current study:

I.Selection of countries: At this stage, a total of six countries, out of a total of 18 countries (excluding islands) in eastern and southern Africa, were purposefully selected for study as follows: Kenya, Tanzania and Uganda (Eastern Africa) and Botswana, South Africa and Zimbabwe (Southern Africa), i.e. three each from eastern and southern Africa.

2.Selection of universities: universities in each of the six countries were identified using several sources that included:

- Catalogue of world universities (http://www.webometrics.info/university_by_country_select.asp.htm)

- Canada's University and College Information Center (http://www.canadian-universities.net/index.html)

- International Network for Higher Education in Africa (2003) (http://www.bc.edu/bc_org/arp/soe/cihe/inhea/index.htm)

- Study in South Africa (http://www.studysa.co.za/index.php)

A total of 59 universities which had own websites were identified from among a total of 65 universities in the six countries.

3.Selection of libraries: It was intended that all academic libraries in the six selected countries be surveyed. As a result, each of the university's website was browsed for information regarding the library's home page URL address. This address was important because it was the one that was used to measure the libraries' performance on the Web. Upon browsing the universities' websites for libraries' URL addresses, only 36 libraries were selected for study based on home page ownership. Excluded from analysis were academic libraries

a) whose URL home page addresses were so long and contained punctuation marks, (e.g. http:// www.unisa.ac.za/Default.asp?Cmd=ViewContent\&ContentID = I7)

b) whose home pages were still under construction.

A complete list of the academic libraries in the six countries is provided in Table I. The last column provides notes on the reasons for exclusion of some of the libraries from the final analysis.

Relevant data were extracted from the Internet between $5^{\text {th }}$ and $20^{\text {th }}$ July 2006 by crawling the web using the SOCSCIBOT computer software (developed by Prof. Mike Thelwall). The extraction of data was conducted only once for each library in an exercise that was so slow and sometimes took as long as three days (day and night) in the case of some libraries, especially those that had large websites. Data were analyzed using the SOCSCIBOT toolkit that consists of matrix and pajek tools in order to:

I. find out the volume of each library's total web pages

2.find out the volume of each library's total out-links

3.measure each library's in-links from and out-links to other libraries in the six countries

4.measure each countries total library web pages and out-links

5.calculate the average number of web pages and out-links per library in each country

6.rank libraries according to the number of pages, out-links and out-links per page.

The Pajek computer software was used to prepare the visual networks. 
Table I Countries, universities and libraries selected for study

\begin{tabular}{|c|c|c|c|}
\hline UNIVERSITY & COUNTRY & LIBRARY HOME PAGE & NOTES \\
\hline Botswana Collge of Agriculture [BCA] & Botswana & & $\begin{array}{l}\text { Under construction } \\
\text { (Excluded) }\end{array}$ \\
\hline University of Botswana [BU] & Botswana & http://www.ub.bw/library/ & \\
\hline Africa Nazarene University [ANU] & Kenya & http://www.anu.ac.ke/library/default.html & \\
\hline $\begin{array}{l}\text { The Catholic Univ. of Eastern Africa } \\
\text { [CUEA] }\end{array}$ & Kenya & http://www.cuea.edu/library/lib.htm & \\
\hline Daystar University [DU] & Kenya & & $\begin{array}{l}\text { No library website } \\
\text { (Excluded) }\end{array}$ \\
\hline Egerton University [EU] & Kenya & http://www.egerton.ac.ke/academics/library/index.php & \\
\hline Maseno University [MASENO] & Kenya & http://www.maseno.ac.ke/library/ & \\
\hline Moi University [MU] & Kenya & http://www.mu.ac.ke/library/index.html & $\begin{array}{l}\text { Under construction } \\
\text { (Excluded) }\end{array}$ \\
\hline $\begin{array}{l}\text { University of Eastern Africa, Baraton } \\
\text { [UEAB] }\end{array}$ & Kenya & http://www.ueab.ac.ke/library/ & \\
\hline University of Nairobi [UONBI] & Kenya & http://library.uonbi.ac.ke/ & \\
\hline $\begin{array}{l}\text { United States International University } \\
\text { [USIU] }\end{array}$ & Kenya & http://www.usiu.ac.ke/library/index.htm & \\
\hline $\begin{array}{l}\text { Jomo Kenyatta Univ. of Agri. \& Tech. } \\
\text { [JKUAT] }\end{array}$ & Kenya & & $\begin{array}{l}\text { No library website } \\
\text { (Excluded) }\end{array}$ \\
\hline Kabarak University [KABARK] & Kenya & http://www.kabarak.ac.ke/library/index.htm & \\
\hline Kenya Methodist University [KEMU] & Kenya & & $\begin{array}{l}\text { No library website } \\
\text { (Excluded) }\end{array}$ \\
\hline $\begin{array}{l}\text { Kiriri Women's Univ of Sci\&Tech } \\
\text { [KWUST] }\end{array}$ & Kenya & & $\begin{array}{l}\text { Under construction } \\
\text { (Excluded) }\end{array}$ \\
\hline $\begin{array}{l}\text { Strathmore University } \\
\text { [STRATHMORE] }\end{array}$ & Kenya & http://www.strathmore.edu/academics/library.html & \\
\hline Cape Peninsula Univ of Tech [CPUT] & South Africa & http://www.cput.ac.za/library/ & \\
\hline $\begin{array}{l}\text { Central Univ of Technology. Free State } \\
\text { [CUT] }\end{array}$ & South Africa & http://www.cut.ac.za/web/academics/library/homepage & \\
\hline Durban Institute of Technology [DUT] & South Africa & http://library.dit.ac.za/index.html & \\
\hline $\begin{array}{l}\text { Nelson Mandela Metropolitan Univ } \\
\text { [NMMU] }\end{array}$ & South Africa & http://www.nmmu.ac.za/default.asp?id=2330\&bhcp $=I$ & $\begin{array}{l}\text { Un-crawlable address } \\
\text { (Excluded) }\end{array}$ \\
\hline Rhodes University [RU] & South Africa & http://www.ru.ac.za/library/ & \\
\hline Stellenbosch University [SUN] & South Africa & http://www.sun.ac.za/library/ & \\
\hline $\begin{array}{l}\text { Tshwane University of Technology } \\
\text { [TUT] }\end{array}$ & South Africa & http://lib.tut.ac.za/ & \\
\hline $\begin{array}{l}\text { Univ of KwaZulu Natal [UKZN - } \\
\text { WEST] }\end{array}$ & South Africa & http://www.ukzn.ac.za/westvillelibrary/ & \\
\hline $\begin{array}{l}\text { Univ of KwaZulu Natal [UKZN - } \\
\text { HOWARD] }\end{array}$ & South Africa & http://www.library.und.ac.za & Used www.library.und.ac.za \\
\hline $\begin{array}{l}\text { Univ of KwaZulu Natal [UKZN - } \\
\text { HOWARD] }\end{array}$ & South Africa & http://www.library.und.ac.za/med/medical.htm & Used www.library.und.ac.za \\
\hline $\begin{array}{l}\text { Univ of KwaZulu Natal [UKZN - } \\
\text { HOWARD] }\end{array}$ & South Africa & http://www.library.unp.ac.za/ & Used www.library.und.ac.za \\
\hline University of Cape Town [UCT] & South Africa & http://www.lib.uct.ac.za & \\
\hline University of Fort Hare [UFH] & South Africa & http://www.ufh.ac.za/library/index.html & \\
\hline University of Johannesburg [U]] & South Africa & http://www.uj.ac.za/library & \\
\hline $\begin{array}{l}\text { University of Limpopo (North) } \\
\text { [UNORTH] }\end{array}$ & South Africa & http://www.unorth.ac.za/Library/index.html & \\
\hline University of Pretoria [UP] & South Africa & http://www.ais.up.ac.zal & \\
\hline University of South Africa [UNISA] & South Africa & $\begin{array}{l}\text { http://www.unisa.ac.za/ } \\
\text { Default.asp?Cmd =ViewContent\&Content/D =17 }\end{array}$ & $\begin{array}{l}\text { Un-crawlable address } \\
\text { (Excluded) }\end{array}$ \\
\hline University of the Free State [UOVS] & South Africa & http://www.uovs.ac.za/faculties/index.php?FCode $=12$ & $\begin{array}{l}\text { Un-crawlable address } \\
\text { (Excluded) }\end{array}$ \\
\hline University of the North [UNORTH] & South Africa & http://www.unorth.ac.za/Library/index.html & \\
\hline
\end{tabular}




\begin{tabular}{|c|c|c|c|}
\hline $\begin{array}{l}\text { University of the Western Cape } \\
\text { [UWC] }\end{array}$ & South Africa & http://www.uwc.ac.za/library/ & \\
\hline University of Venda [UNIVEN] & South Africa & http://www.univen.ac.za/library/library.php & \\
\hline University of Witwatersrand [WITS] & South Africa & http://www.wits.ac.za/library/index.htm & \\
\hline Vaal University of Technology [VUT] & South Africa & http://www.vut.ac.za/metadot/index.pl?id=2860 & $\begin{array}{l}\text { Un-clawlable address } \\
\text { (Excluded) }\end{array}$ \\
\hline Walter Sisulu University [WSU] & South Africa & http://www.wsu.ac.za/library/mainlibrary.htm & \\
\hline $\begin{array}{l}\text { Dar es Salaam Institute of Technology } \\
\text { [DIT] }\end{array}$ & Tanzania & & $\begin{array}{l}\text { University site couldn't be } \\
\text { accessed (Excluded) }\end{array}$ \\
\hline Dar es Salaam University [UDSM] & Tanzania & http://www.udsm.ac.tz/library/index.htm & \\
\hline $\begin{array}{l}\text { Hubert Kairuki Memorial University } \\
\text { [HKMU] }\end{array}$ & Tanzania & & $\begin{array}{l}\text { No library website } \\
\text { (Excluded) }\end{array}$ \\
\hline International Med. \& Tech Univ [IMTU] & Tanzania & & $\begin{array}{l}\text { No library website } \\
\text { (Excluded) }\end{array}$ \\
\hline Mount Meru University [MMU] & Tanzania & & $\begin{array}{l}\text { No Library website } \\
\text { (Excluded) }\end{array}$ \\
\hline Mzumbe University [MZUMBE] & Tanzania & http://www.mzumbe.ac.tz/libary.htm & \\
\hline $\begin{array}{l}\text { Sokoine University of Agriculture } \\
\text { [SUANET] }\end{array}$ & Tanzania & http://snalwww.suanet.ac.tz/index.html & \\
\hline Bugema University [BUGEMA] & Uganda & & $\begin{array}{l}\text { University site couldn't be } \\
\text { accessed (Excluded) }\end{array}$ \\
\hline Central Bugema University [CBU] & Uganda & & $\begin{array}{l}\text { No Library website } \\
\text { (Excluded) }\end{array}$ \\
\hline Islamic University in Uganda [IUU] & Uganda & & $\begin{array}{l}\text { No Library website } \\
\text { (Excluded) }\end{array}$ \\
\hline Kampala International University [KIU] & Uganda & $\begin{array}{l}\text { http://www.kiu.ac.ug/ } \\
\text { index.php?option=com_content\&task=blogcategory\&id=79\&/t } \\
\text { emid=56\&lang=en }\end{array}$ & $\begin{array}{l}\text { Un-crawlable address } \\
\text { (Excluded) }\end{array}$ \\
\hline Makerere University [MAKERERE] & Uganda & http://www.makerere.ac.ug/mulib/ & \\
\hline $\begin{array}{l}\text { Mbarara University of Sci. \& Tech } \\
\text { [MBARARA] }\end{array}$ & Uganda & $\begin{array}{l}\text { http://www.must.ac.ug/ } \\
\text { index.php?option = content\&task=view\&id = 20\&/temid }=34\end{array}$ & $\begin{array}{l}\text { Un-crawlable address } \\
\text { (Excluded) }\end{array}$ \\
\hline Africa University [AFRICAU] & Zimbabwe & http://www.africau.edu/Library/index.htm & \\
\hline Chinhoyi University [CHINHOVI] & Zimbabwe & http://www.cut.ac.zw/library/home.html & \\
\hline Midlands State University [MSU] & Zimbabwe & http://www.msu.ac.zw/libraries/index.php & \\
\hline $\begin{array}{l}\text { National University of Sci. \& Techn. } \\
\text { [NUST] }\end{array}$ & Zimbabwe & http://www.nust.ac.zw/library/index.htm & \\
\hline Solusi University [SOLUSI] & Zimbabwe & & $\begin{array}{l}\text { No library website } \\
\text { (Excluded) }\end{array}$ \\
\hline University of Zimbabwe [UZ] & Zimbabwe & http://www.uz.ac.zw/library/ & \\
\hline
\end{tabular}

\section{Results}

This section presents results and covers the following main areas of study: location of the library(ies) link on university website(s); essential web-based services offered by each library service; number of pages and out-links; distribution of library web pages and out-links by country; most commonly targeted web pages and Top Level Domains (TLDs); number of in- and out-links among the libraries; and the libraries' networks

6.1 Location of library links on the universities' websites

The location of a library link on the university's home page was evaluated so as to assess the ease of accessibility of the library's website. It was noted that out of the total 36 library websites surveyed, 34 (94.4\%) library links were provided on the respective university home pages. Only two (5.6\%) library websites had accessibility through the academic programs' directory.

\subsection{Essential web-based online services}

Libraries' websites were compared using four essential services, i.e. the provision of search engines, web-based Online Public Access Catalogs (OPACs), Web-based forms (e.g. feedback forms, etc) and library guides (including training and orientation resources) as shown in Table 2. It was observed that 12 (33.3\%) libraries provided search engine options on their websites while the $29(80.6 \%)$ libraries offered clients with the OPAC. There were six libraries that provided web 
forms while majority of the libraries (30 or $83.3 \%$ ) posted special library guides (orientation and training resources) on their websites.

\subsection{Number of pages and out-links}

Table 3 provides the rank distribution of the libraries according to the total number of web pages, out-links and out-links per page. There were a total of 22508 web pages and 275775 out-links, a situation that generated an average of I2.2523 out-links per page. Dividing the total number of pages and out-links by the total number of libraries yielded 625.2 web pages and 7660.4 out-links per library. On overall, the RU library is ranked number one with 628 pages, 19694 out-links and 31.3599 out-links per page followed by [all in the order of pages, out-links and out-links per page] CPUT library ( 335 , 9774, 29.1761), SUN library (917, 16784, 18.3032), UKZN - Howard College Campus library (218, 9578, 43.9358), and the UCT libraries (16468, 1736I6, 10.5426). Ranking number one according to the total number of pages was the UCT library followed by UP, SUN, UFH, and RU libraries in that order while the top ranking libraries in terms of the total number of out-links were UCT, RU, SUN, UP, and CPUT. The UKZN - HOWARD libraries topped the list of the libraries with the most out-links per page (i.e. 43.9358) followed by RU library (31.3599), CPUT library (29.176I), UKZN Westville library (25.8125) and Strathmore library (23.0000), etc.

Table 2 Provision of web-based essential services

\begin{tabular}{|c|c|c|c|c|c|}
\hline No. & Library website & Search Engine & OPAC & Web forms & Library guides \\
\hline I & www.ru.ac.za/library & $\checkmark$ & $\checkmark$ & $\checkmark$ & $\checkmark$ \\
\hline 2 & www.ais.up.ac.za & $\checkmark$ & $\checkmark$ & $\checkmark$ & $\checkmark$ \\
\hline 3 & www.cut.ac.za/web/academics/library & $\checkmark$ & $\checkmark$ & $\checkmark$ & $\checkmark$ \\
\hline 4 & www.ufh.ac.za/library & $\checkmark$ & $\checkmark$ & $\checkmark$ & $\checkmark$ \\
\hline 5 & www.wits.ac.za/library & $\checkmark$ & $\checkmark$ & $\checkmark$ & $\checkmark$ \\
\hline 6 & www.makerere.ac.ug/mulib & $\checkmark$ & $\checkmark$ & $x$ & $\checkmark$ \\
\hline 7 & http://snalwww.suanet.ac.tz & $\checkmark$ & $\checkmark$ & $x$ & $\checkmark$ \\
\hline 8 & www.msu.ac.zw/libraries & $\checkmark$ & $\checkmark$ & $x$ & $\checkmark$ \\
\hline 9 & http://library.dit.ac.za & $\checkmark$ & $\checkmark$ & $x$ & $\checkmark$ \\
\hline 10 & www.uj.ac.za/library & $\checkmark$ & $\checkmark$ & $x$ & $\checkmark$ \\
\hline 11 & www.uz.ac.zw/library & $\checkmark$ & $\checkmark$ & $x$ & $\checkmark$ \\
\hline 12 & www.ueab.ac.ke/library & $x$ & $\checkmark$ & $\checkmark$ & $\checkmark$ \\
\hline 13 & www.cput.ac.za/library & $x$ & $\checkmark$ & $x$ & $\checkmark$ \\
\hline 14 & www.sun.ac.za/library & $x$ & $\checkmark$ & $x$ & $\checkmark$ \\
\hline 15 & www.library.und.ac.za & $x$ & $\checkmark$ & $x$ & $\checkmark$ \\
\hline 16 & www.lib.uct.ac.za & $x$ & $\checkmark$ & $x$ & $\checkmark$ \\
\hline 17 & www.uwc.ac.za/library & $x$ & $\checkmark$ & $x$ & $\checkmark$ \\
\hline 18 & www.ub.bw/library & $x$ & $\checkmark$ & $x$ & $\checkmark$ \\
\hline 19 & www.ukzn.ac.za/westvillelibrary & $x$ & $\checkmark$ & $x$ & $\checkmark$ \\
\hline 20 & http://lib.tut.ac.za & $x$ & $\checkmark$ & $x$ & $\checkmark$ \\
\hline 21 & www.cut.ac.zw/library & $x$ & $\checkmark$ & $x$ & $\checkmark$ \\
\hline 22 & http://library.uonbi.ac.ke/website & $x$ & $\checkmark$ & $x$ & $\checkmark$ \\
\hline 23 & www.usiu.ac.ke/library & $x$ & $\checkmark$ & $x$ & $\checkmark$ \\
\hline 24 & www.anu.ac.ke/library & $\checkmark$ & $x$ & $x$ & $\checkmark$ \\
\hline 25 & www.nust.ac.zw/library & $x$ & $\checkmark$ & $x$ & $\checkmark$ \\
\hline 26 & www.univen.ac.za/library & $x$ & $\checkmark$ & $x$ & $\checkmark$ \\
\hline 27 & www.udsm.ac.tz/library & $x$ & $\checkmark$ & $x$ & $\checkmark$ \\
\hline 28 & www.unorth.ac.za/library & $x$ & $\checkmark$ & $x$ & $\checkmark$ \\
\hline 29 & www.africau.edu/Library & $x$ & $\checkmark$ & $x$ & $\checkmark$ \\
\hline 30 & www.kabarak.ac.ke/library & $x$ & $x$ & $x$ & $\checkmark$ \\
\hline 31 & www.maseno.ac.ke/library & $x$ & $x$ & $x$ & $x$ \\
\hline 32 & www.egerton.ac.ke/academics/library & $x$ & $x$ & $x$ & $x$ \\
\hline
\end{tabular}

SA Jnl Libs \& Info Sci 2007, 73(I) 


\begin{tabular}{|c|c|c|c|c|c|}
\hline 33 & www.strathmore.edu/academics & $\mathrm{x}$ & $x$ & $x$ & $\mathrm{x}$ \\
\hline 34 & www.wsu.ac.za/library & $x$ & $x$ & $x$ & $x$ \\
\hline 35 & www.cuea.edu/library & $\mathrm{x}$ & $x$ & $x$ & $\mathrm{x}$ \\
\hline 36 & www.mzumbe.ac.tz/library & $x$ & $x$ & $x$ & $\mathrm{x}$ \\
\hline
\end{tabular}

Key: $\checkmark=$ Service available; $x=$ Service not available

Table 3 Number of pages and out-links

\begin{tabular}{|c|c|c|c|c|c|c|c|c|}
\hline \multirow[b]{2}{*}{ No } & \multirow[b]{2}{*}{ Overall rank } & \multirow[b]{2}{*}{ Site } & \multicolumn{2}{|c|}{ Pages } & \multicolumn{2}{|c|}{ Out-links } & \multicolumn{2}{|c|}{ Out-links per page } \\
\hline & & & $\mathbf{r}$ & $f$ & $\mathbf{r}$ & f & $\mathbf{r}$ & $f$ \\
\hline I & 1 & www.ru.ac.za/library & 5 & 628 & 2 & 19694 & 2 & 31.3599 \\
\hline 2 & 2 & www.cput.ac.za/library & 8 & 335 & 5 & 9774 & 3 & 29.1761 \\
\hline 3 & 3 & www.sun.ac.za/library & 3 & 917 & 3 & 16784 & 11 & 18.3032 \\
\hline 4 & 4 & www.library.und.ac.za & 10 & 218 & 7 & 9578 & 1 & 43.9358 \\
\hline 5 & 5 & www.lib.uct.ac.za & 1 & 16468 & 1 & 173616 & 22 & 10.5426 \\
\hline 6 & 6 & www.uwc.ac.za/library & 7 & 436 & 8 & 8335 & 10 & 19.1170 \\
\hline 7 & 7 & www.ufh.ac.za/library & 4 & 664 & 6 & 9658 & 18 & 14.5452 \\
\hline 8 & 8 & www.ais.up.ac.za & 2 & 1488 & 4 & 14789 & 23 & 9.9388 \\
\hline 9 & 9 & www.ub.bw/library & 14 & 49 & 11 & 1033 & 7 & 21.0816 \\
\hline 10 & 10 & www.ukzn.ac.za/westvillelibrary & 16 & 32 & 13 & 826 & 4 & 25.8125 \\
\hline II & 11 & www.wits.ac.za/library & 6 & 451 & 9 & 5320 & 19 & II.7960 \\
\hline 12 & 12 & www.makerere.ac.ug/mulib & 13 & 55 & 12 & 911 & 12 & 16.5636 \\
\hline 13 & 13 & http://snalwww.suanet.ac.tz & 15 & 45 & 14 & 671 & 17 & 14.9111 \\
\hline 14 & 14 & http://lib.tut.ac.za & 22 & 17 & 18 & 339 & 9 & 19.9412 \\
\hline 15 & 15 & www.msu.ac.zw/libraries & 17 & 27 & 17 & 403 & 16 & 14.9259 \\
\hline 16 & 15 & www.maseno.ac.ke/library & 9 & 327 & 10 & 1340 & 31 & 4.0979 \\
\hline 17 & 16 & www.cut.ac.zw/library & 19 & 20 & 19 & 316 & 13 & 15.800 \\
\hline 18 & 17 & http://library.uonbi.ac.ke/website & 12 & 62 & 15 & 523 & 25 & 8.4355 \\
\hline 19 & 18 & www.egerton.ac.ke/academics/library & 27 & 7 & 22 & 159 & 6 & $22.7 \mid 43$ \\
\hline 20 & 19 & http://library.dit.ac.za & II & 76 & 16 & 486 & 29 & 6.3947 \\
\hline 21 & 20 & www.usiu.ac.ke/library & 18 & 21 & 20 & 196 & 24 & 9.3333 \\
\hline 22 & 21 & www.strathmore.edu/academics & 29 & 1 & 30 & 23 & 5 & 23.0000 \\
\hline 23 & 22 & www.kabarak.ac.ke/library & 26 & 8 & 24 & 125 & 14 & 15.625 \\
\hline 24 & 23 & www.anu.ac.ke/library & 17 & 27 & 21 & 185 & 27 & 6.8519 \\
\hline 25 & 24 & www.nust.ac.zw/library & 24 & 12 & 23 & 131 & 20 & 10.9167 \\
\hline 26 & 25 & www.cut.ac.za/web/academics/library & 29 & 1 & 31 & 20 & 8 & 20.000 \\
\hline 27 & 26 & www.wsu.ac.za/library & 28 & 3 & 28 & 45 & 15 & 15.000 \\
\hline 28 & 26 & www.univen.ac.za/library & 25 & 10 & 25 & 108 & 21 & 10.8000 \\
\hline 29 & 27 & www.uj.ac.za/library & 20 & 19 & 24 & 125 & 28 & 6.5789 \\
\hline 30 & 28 & www.ueab.ac.ke/library & 23 & 13 & 27 & 90 & 26 & 6.9231 \\
\hline 31 & 29 & www.uz.ac.zw/library & 21 & 18 & 26 & 101 & 30 & 5.6111 \\
\hline 32 & 30 & www.udsm.ac.tz/library & 18 & 21 & 30 & 23 & 34 & 1.0952 \\
\hline 33 & 31 & www.unorth.ac.za/library & 25 & 10 & 29 & 24 & 33 & 2.4000 \\
\hline
\end{tabular}




\begin{tabular}{lllllllll}
34 & 31 & $w w w . c u e a . e d u / l i b r a r y$ & 19 & 20 & 32 & 19 & 36 & 0.9500 \\
35 & 32 & www.africau.edu/Library & 29 & 1 & 33 & 4 & 32 & 4.0000 \\
36 & 33 & www.mzumbe.ac.tz/library & 29 & 1 & 34 & 1 & 35 & 1.0000 \\
& TOTAL & & & $\mathbf{2 2 5 0 8}$ & $\mathbf{2 7 5 7 7 5}$ & $\mathbf{1 2 . 2 5 2 3}$ \\
\hline
\end{tabular}

Key: $r=\operatorname{rank}, f=$ frequency (i.e. number of pages, out-links and out-links per page, respectively)

6.4 Distribution of library web pages and out-links by country

The total number of library web pages and out-links were computed for each country in order to find out the most productive country. South Africa was the leading with 21793 library web pages followed by Kenya (486), Tanzania (67), Zimbabwe (58), Uganda (55) and Botswana (49). The number of out-links was highest in South Africa (269837) followed by Kenya (2660), Botswana (1033), Uganda (9II), Tanzania (695) and Zimbabwe (639). When ranked according to the average number of pages per library, South Africa was the leading with 1210.72 pages per academic library followed by Uganda (55.00), Kenya (54), Botswana (49), Tanzania (22.33), and Zimbabwe (14.50). The distribution pattern of the number of out-links per library was as follows: South Africa (14990.94), Botswana (1033.00), Uganda (911.00), Kenya (295.56), Tanzania (23I.67), and Zimbabwe (I59.75).

Table 4 Distribution of library web pages and out-links by country

\begin{tabular}{|c|c|c|c|c|c|}
\hline no. & country & pages & outlinks & pages/library & outlinks/library \\
\hline 1 & South Africa & 21793 & 269837 & 1210.72 & 14990.94 \\
\hline 2 & Kenya & 486 & 2660 & 54.00 & 295.56 \\
\hline 3 & Tanzania & 67 & 695 & 22.33 & 231.67 \\
\hline 4 & Zimbabwe & 58 & 639 & 14.50 & 159.75 \\
\hline 5 & Uganda & 55 & 911 & 55.00 & 911.00 \\
\hline 6 & Botswana & 49 & 1033 & 49.00 & 1033.00 \\
\hline
\end{tabular}

6.5 Most commonly targeted web pages and Top Level Domains (TLDs)

Table 5 provides 74 top ranking sites and TLDs that are commonly targeted by the academic libraries in the region. These include, in descending order, adobe.com/ (104), nlm.nih.gov/ (103), biblioline.nisc.com/ (91), thor.sabinet.co.za/ (83), sciencedirect.com/ (69), gateway.ovid.com/ (58), serialssolutions.com/ (53) and search.rdsinc.com/ (52). Others are home.ncifcrf.gov/ (46), scirus.com/ (44), mg.co.za/ (43), isiknowledge.com/ (38), opencube.com (31), search.epnet.com/ (31). Adobe is a company that develops a variety of computer programs such as the Adobe Engagement Platform - built around Adobe PDF and Flash technology - that greatly enhances how people create, manage, deliver and engage with information. The National Library of Medicine (NLM) on the other hand, is a medical library based on the campus of the National Institutes of Health in Bethesda, Maryland. The company collects materials and provides information and research services in all areas of biomedicine and health care. One of its well known products is the MEDLINE database. The National Services Corporation (NISC, USA) provides information products that are accessed through BiblioLine, a Web search service, or on CD-ROM. BiblioLine is a straightforward yet sophisticated approach to online searching via the internet. SABINET is the short form for South African Bibliographic Network. SABINET facilitates electronic access to information, largely through the provision of bibliographies while ScienceDirect is a an online database that offers more than a quarter of the world's scientific, medical and technical information online. Its coverage include over 2,000 peerreviewed journals; hundreds of book series, handbooks and reference works; and back files.

An examination of the top level domains indicates that the .com or .co TLDs were the most common, recording 59 hits (i.e. $79.7 \%$ of the 74 top ranking sites or web pages). In the second position was .edu ( 4 or $5.4 \%$ ). The .gov, .net and .org TLDs recorded 3 hits each.

It was observed that there were a variety of sites that are targeted by E\&S African academic libraries. When classified according to the types of services or products these sites provide, the following categories emerged in the top ranking web sites: news sites (e.g. nytimes.com, daily-mail.co.zm, etc.), search engines (e.g. google.com), electronic databases (e.g. sabinet.co.za), database publishers (e.g. nlm.nih.gov, sciencedirect.com, etc), computer software companies (e.g. SA Jnl Libs \& Info Sci 2007, 73(1) 
adobe.com), government sites (e.g. gov.za), and electronic books and general reference resources (e.g. yourdictionary.com).

Table 5 Most commonly targeted web pages and TLDs

\begin{tabular}{|c|c|c|c|c|c|c|c|}
\hline No. & Rank & TLD targeted & Hits & No. & Rank & TLD targeted & Hits \\
\hline 1 & 1 & .adobe.com/ & 104 & 38 & 19 & .observer.co.uk/ & 24 \\
\hline 2 & 2 & .nlm.nih.gov/ & 103 & 39 & 19 & wwwlib.umi.com/dissertations/ & 24 \\
\hline 3 & 3 & biblioline.nisc.com/ & 91 & 40 & 20 & .library.uq.edu.au/training/ & 23 \\
\hline 4 & 4 & thor.sabinet.co.za/ & 83 & 41 & 20 & .webstat.com & 23 \\
\hline 5 & 5 & sciencedirect.com/ & 69 & 42 & 20 & .jutalaw.co.za/ & 23 \\
\hline 6 & 6 & gateway.ovid.com/ & 58 & 43 & 20 & .update-software.com/ & 23 \\
\hline 7 & 7 & serialssolutions.com/ & 53 & 44 & 20 & .rekord.co.za/ & 23 \\
\hline 8 & 8 & search.rdsinc.com/ & 52 & 45 & 20 & .safm.co.za/ & 23 \\
\hline 9 & 9 & home.ncifcrf.gov/ & 46 & 46 & 20 & .naspers.co.za/ & 23 \\
\hline 10 & 10 & .scirus.com/ & 44 & 47 & 21 & .nepru.org.na & 22 \\
\hline 11 & 11 & .mg.co.za/ & 43 & 48 & 21 & .the-times.co.uk/ & 22 \\
\hline 12 & 12 & isiknowledge.com/ & 38 & 49 & 21 & .arttoday.com/ & 22 \\
\hline 13 & 13 & opencube.com & 31 & 50 & 21 & $. s k y . c o m /$ & 22 \\
\hline 14 & 13 & search.epnet.com/ & 31 & 51 & 21 & .public.iastate.edu/ & 22 \\
\hline 15 & 14 & .nytimes.com/ & 30 & 52 & 21 & dictionary.oed.com/ & 22 \\
\hline 16 & 15 & .zoutnet.co.za/ & 28 & 53 & 22 & .paarlpost.co.za/ & 21 \\
\hline 17 & 15 & .daily-mail.co.zm/ & 28 & 54 & 23 &. sabcnews.com/ & 20 \\
\hline 18 & 15 & .zamnet.zm & 28 & 55 & 23 & .gov.za/ & 20 \\
\hline 19 & 15 & fingaz.co.zw & 28 & 56 & 23 & xe.net/ucd/ & 20 \\
\hline 20 & 16 & .memeza.com/zambia/ & 27 & 57 & 23 & .pta-online.co.za/ & 20 \\
\hline 21 & 16 & .witness.co.za/ & 27 & 58 & 23 & .portland.com/ & 20 \\
\hline 22 & 16 & .headlines.co.za/ & 27 & 59 & 24 & google.com/ & 19 \\
\hline 23 & 16 & wagne.net & 27 & 60 & 25 &. swetsnetnavigator.nl/direct/ & 18 \\
\hline 24 & 17 & .123 world.com/ & 26 & 61 & 25 & afronet.org.za/monitor.htm & 18 \\
\hline 25 & 17 & .news24.co.za/ & 26 & 62 & 25 & lexis-nexis.com/professional/ & 18 \\
\hline 26 & 17 & sowetan.co.za/ & 26 & 63 & 25 & .economist.com.na & 18 \\
\hline 27 & 17 & .jstor.org/ & 26 & 64 & 25 & .newafrica.com/ & 18 \\
\hline 28 & 18 & suntimes.co.za/ & 25 & 65 & 25 & .herald.co.zw/ & 18 \\
\hline 29 & 18 & .sundaymail.co.zw/ & 25 & 66 & 25 & nigeriacentral.com/ & 18 \\
\hline 30 & 18 & .republikein.com.na & 25 & 67 & 25 & libraryspot.com/ & 18 \\
\hline 31 & 18 & .nyenzi.co.tz/ & 25 & 68 & 25 & .namibianews.com & 18 \\
\hline 32 & 18 & galenet.galegroup.com/ & 25 & 69 & 25 & .nyenzi.co.tz & 18 \\
\hline 33 & 19 & library.uncg.edu/ & 24 & 70 & 25 & .yourdictionary.com/ & 18 \\
\hline 34 & 19 & .nn.independent.co.za/ & 24 & 71 & 25 & .namibian.com.na & 18 \\
\hline 35 & 19 & time.com/time/ & 24 & 72 & 26 & wagne.net/messager & 17 \\
\hline 36 & 19 & .theexpress.com & 24 & 73 & 26 & .bday.co.za/ & 17 \\
\hline 37 & 19 & .bbjonline.com/ & 24 & 74 & 26 & wisc.edu/ltc/ & 17 \\
\hline
\end{tabular}


Table 6 In- and out-links among the academic libraries in the six countries

\begin{tabular}{|c|c|c|c|c|c|c|c|c|}
\hline Name & $\begin{array}{c}\text { Page } \\
\text { inlinks }\end{array}$ & $\begin{array}{c}\text { Directory } \\
\text { inlinks }\end{array}$ & $\begin{array}{l}\text { Domain } \\
\text { inlinks }\end{array}$ & $\begin{array}{c}\text { Site } \\
\text { inlinks }\end{array}$ & $\begin{array}{c}\text { Page } \\
\text { outlinks }\end{array}$ & $\begin{array}{c}\text { Directory } \\
\text { outlinks }\end{array}$ & $\begin{array}{l}\text { Domain } \\
\text { outlinks }\end{array}$ & $\begin{array}{c}\text { Site } \\
\text { outlinks }\end{array}$ \\
\hline library.und.ac.za & 40 & 8 & 5 & 5 & 0 & 0 & 0 & 0 \\
\hline lib.uct.ac.za & 15 & 15 & 6 & 6 & 25 & 25 & 15 & 14 \\
\hline .uz.ac.zw/library & 10 & 7 & 1 & I & 0 & 0 & 0 & 0 \\
\hline .sun.ac.za/library & 9 & 8 & 6 & 6 & 13 & 13 & 3 & 3 \\
\hline .wits.ac.za/library & 7 & 6 & 4 & 4 & 2 & 2 & 2 & 2 \\
\hline .uwc.ac.za/library & 6 & 6 & 3 & 3 & 10 & 10 & 9 & 9 \\
\hline .univen.ac.za/library & 6 & 5 & 5 & 5 & 0 & 0 & 0 & 0 \\
\hline ais.up.ac.za & 5 & 4 & 4 & 4 & 6 & 6 & 6 & 6 \\
\hline .ru.ac.za/library & 5 & 5 & 3 & 3 & 19 & 10 & 10 & 10 \\
\hline .cput.ac.za/library & 4 & 4 & 3 & 3 & 0 & 0 & 0 & 0 \\
\hline .wsu.ac.za/library & 4 & 3 & 3 & 3 & 0 & 0 & 0 & 0 \\
\hline .ukzn.ac.za/westvillelibrary & 4 & 3 & 3 & 3 & 34 & 3 & 1 & 1 \\
\hline .uj.ac.za/library & 4 & 3 & 3 & 3 & 0 & 0 & 0 & 0 \\
\hline library.dit.ac.za & 3 & 2 & 2 & 2 & 10 & 10 & 10 & 10 \\
\hline .ufh.ac.za/library & 3 & 3 & 2 & 1 & 1 & 1 & 1 & 1 \\
\hline .cut.ac.za/web/academics/library & 2 & 2 & 2 & 2 & 0 & 0 & 0 & 0 \\
\hline .unorth.ac.za/library & 2 & 2 & 2 & 2 & 0 & 0 & 0 & 0 \\
\hline lib.tut.ac.za & 1 & 1 & 1 & 1 & 0 & 0 & 0 & 0 \\
\hline mzumbe.ac.tz/library & 1 & 1 & 1 & 1 & 0 & 0 & 0 & 0 \\
\hline makerere.ac.ug/mulib & 0 & 0 & 0 & 0 & 0 & 0 & 0 & 0 \\
\hline .ub.bw/library & 0 & 0 & 0 & 0 & 0 & 0 & 0 & 0 \\
\hline .anu.ac.ke/library & 0 & 0 & 0 & 0 & 0 & 0 & 0 & 0 \\
\hline .cuea.edu/library & 0 & 0 & 0 & 0 & 0 & 0 & 0 & 0 \\
\hline .egerton.ac.ke/academics/library & 0 & 0 & 0 & 0 & 0 & 0 & 0 & 0 \\
\hline maseno.ac.ke/library & 0 & 0 & 0 & 0 & 0 & 0 & 0 & 0 \\
\hline .ueab.ac.ke/library & 0 & 0 & 0 & 0 & 0 & 0 & 0 & 0 \\
\hline .usiu.ac.ke/library & 0 & 0 & 0 & 0 & 0 & 0 & 0 & 0 \\
\hline library.uonbi.ac.ke & 0 & 0 & 0 & 0 & 0 & 0 & 0 & 0 \\
\hline .udsm.ac.tz/library & 0 & 0 & 0 & 0 & 0 & 0 & 0 & 0 \\
\hline .africau.edu/library & 0 & 0 & 0 & 0 & 0 & 0 & 0 & 0 \\
\hline .cut.ac.zw/library & 0 & 0 & 0 & 0 & 10 & 7 & 1 & 1 \\
\hline .msu.ac.zw/libraries & 0 & 0 & 0 & 0 & 0 & 0 & 0 & 0 \\
\hline .nust.ac.zw/library & 0 & 0 & 0 & 0 & 0 & 0 & 0 & 0 \\
\hline snalwww.suanet.ac.tz & 0 & 0 & 0 & 0 & 1 & 1 & 1 & I \\
\hline .kabarak.ac.ke/library & 0 & 0 & 0 & 0 & 0 & 0 & 0 & 0 \\
\hline .strathmore.edu/academics/library.html & 0 & 0 & 0 & 0 & 10 & 8 & I & I \\
\hline Total no. of links & 150 & 99 & 61 & 60 & 150 & 99 & 61 & 60 \\
\hline Links per library & 4.17 & 2.75 & 1.69 & 1.67 & 4.17 & 2.75 & 1.69 & 1.67 \\
\hline
\end{tabular}

6.6 Number of in- and out-links among the libraries

Table 6 ranks the libraries according to the total number of page in-links. The Table provides the total number of in- and out-links (page, directory, domain, and site) that each universities received from or gave to the other universities, respectively. For instance, the UKZN [HOWARD] libraries received a total of 40 page links, 8 directory links, 5 domain links and 5 site links from the libraries that were surveyed, while it offered no out-links to any of the libraries. The UCT libraries on the other hand, provided links to other libraries as follows: 25 page and directory out-links, 15 domain outlinks and 14 site out-links. Several university libraries (e.g. MAKERERE, BU, ANU, CUEA, EGERTON, MASENO, UEAB, USIU, UDSM, AFRICAU, NUST, and KABARAK) did not receive links from nor provide links to any of the other libraries. Overall, there were a total of $150,99,61$, and 60 page, directory, domain and site in-links, respectively. On average, each 
university received and produced $4.17,2.75,1.69$, and 1.67 page, directory, domain and site out-links, respectively, as illustrated in Table 6. Another notable observation from Table 6 is that most (approximately 50\%) libraries did not have any in-links from and out-links to other libraries under the scope of this study.

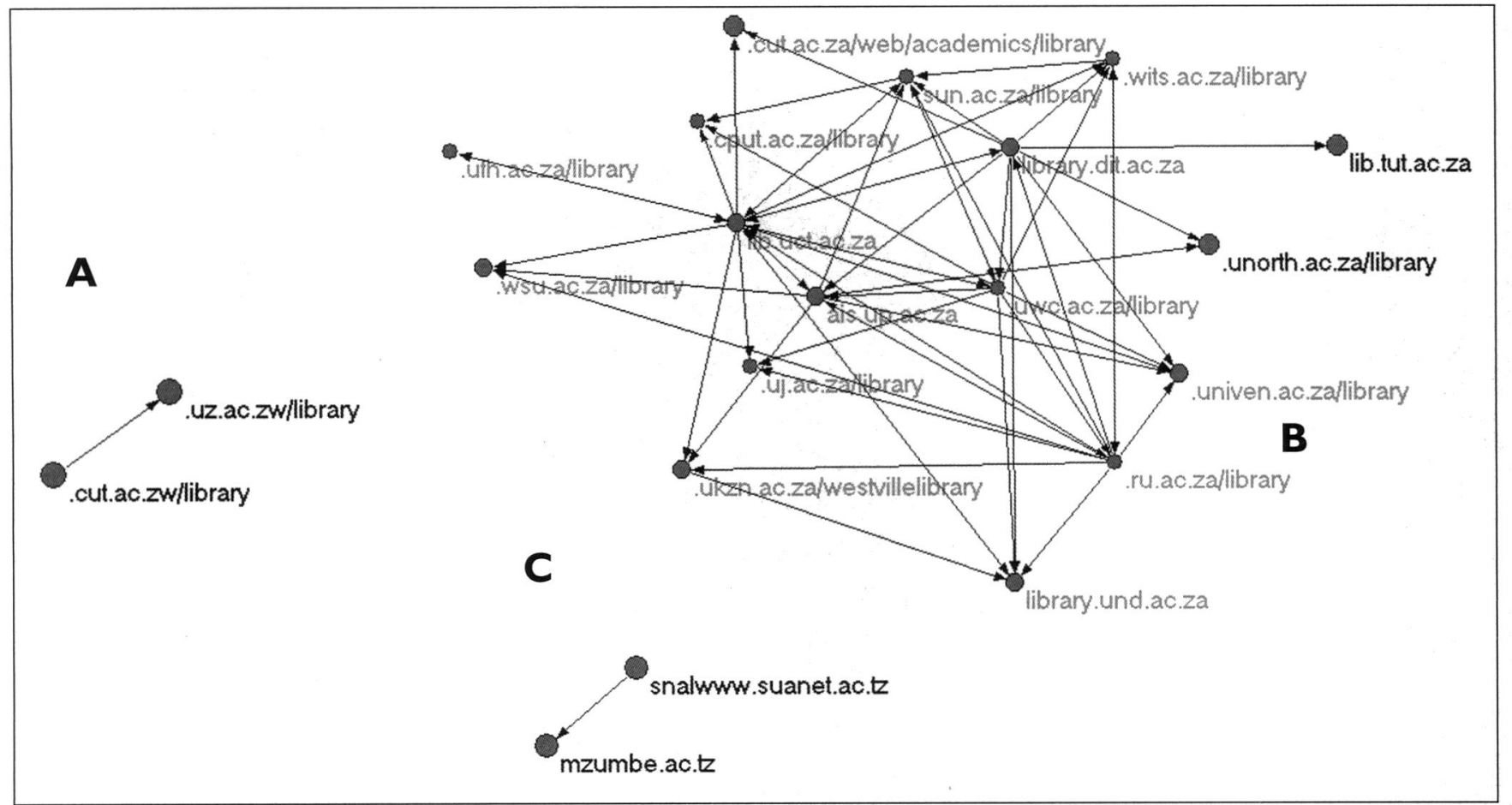

Figure 1 Academic library networks: site in- and out-links

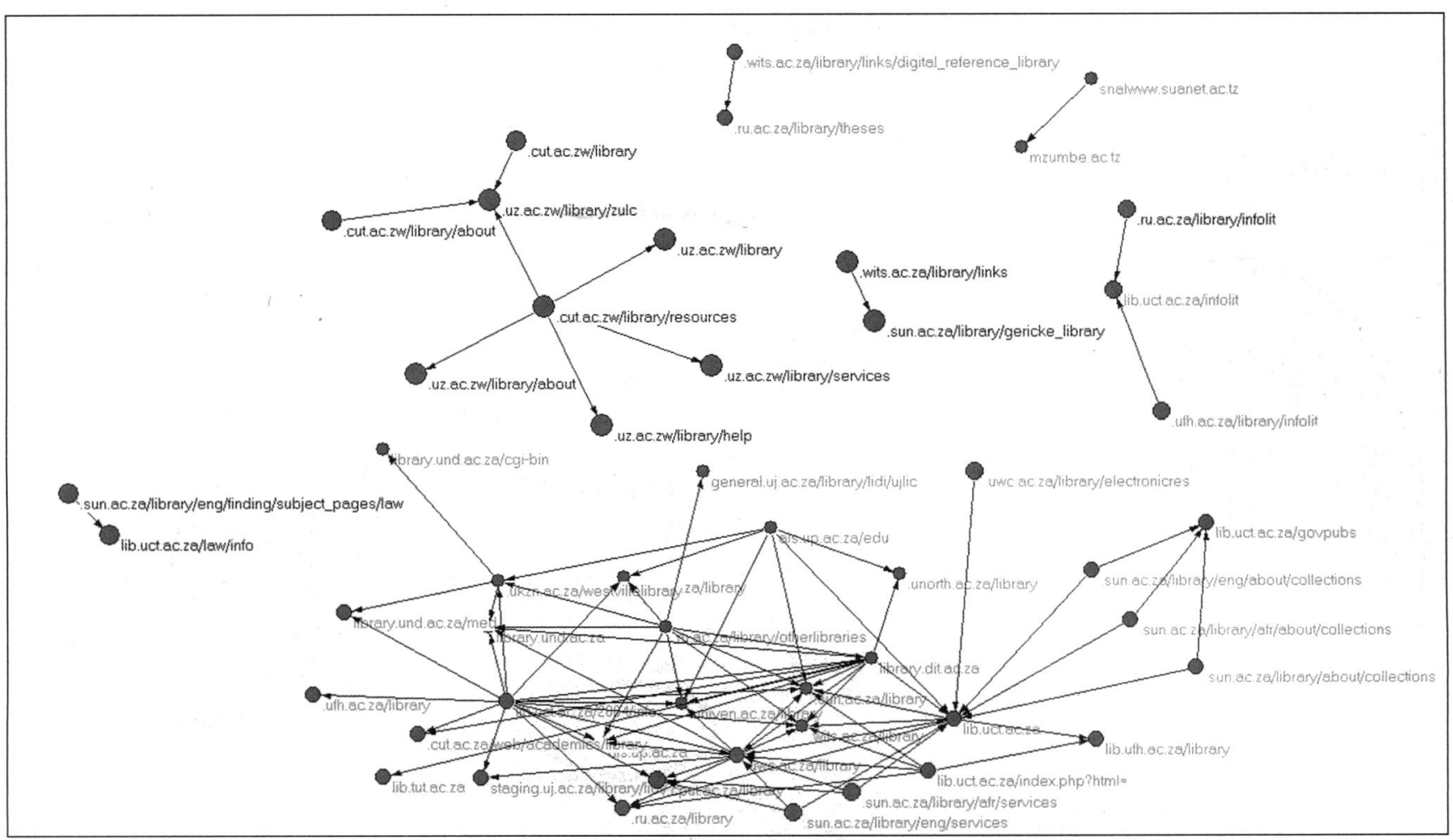

Figure 2 Academic library networks: directory in- and out-links

\subsection{Libraries' networks}

When plotted on a visual map, Table 4 above yields figures I, 2 and 3. Fig I maps the site in-links and out-links among the 36 academic libraries. The map produced three networks, marked A, B and C. A is a network of two academic libraries, namely, the UZ library and the CHINHOVI library, both found in Zimbabwe. Network B consists of 17 university libraries in South Africa while network $C$ is composed of two academic libraries in Tanzania. It can be noted that Kenya's, 
Uganda's, and Botswana's university libraries are not represented mainly because these libraries do not have any links to or from any other library investigated.

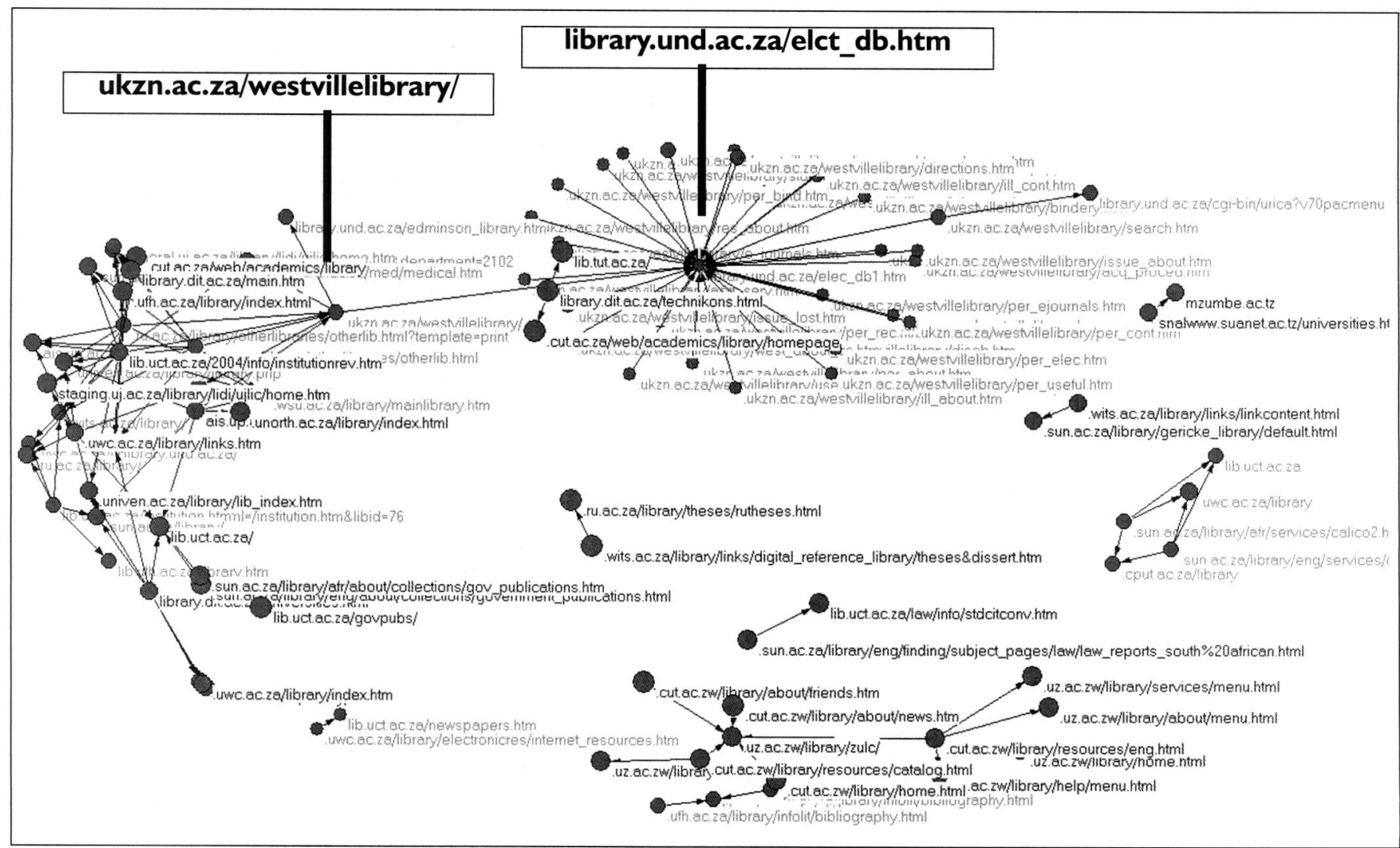

Figure 3 Academic libraries' network map: page in- and out-links

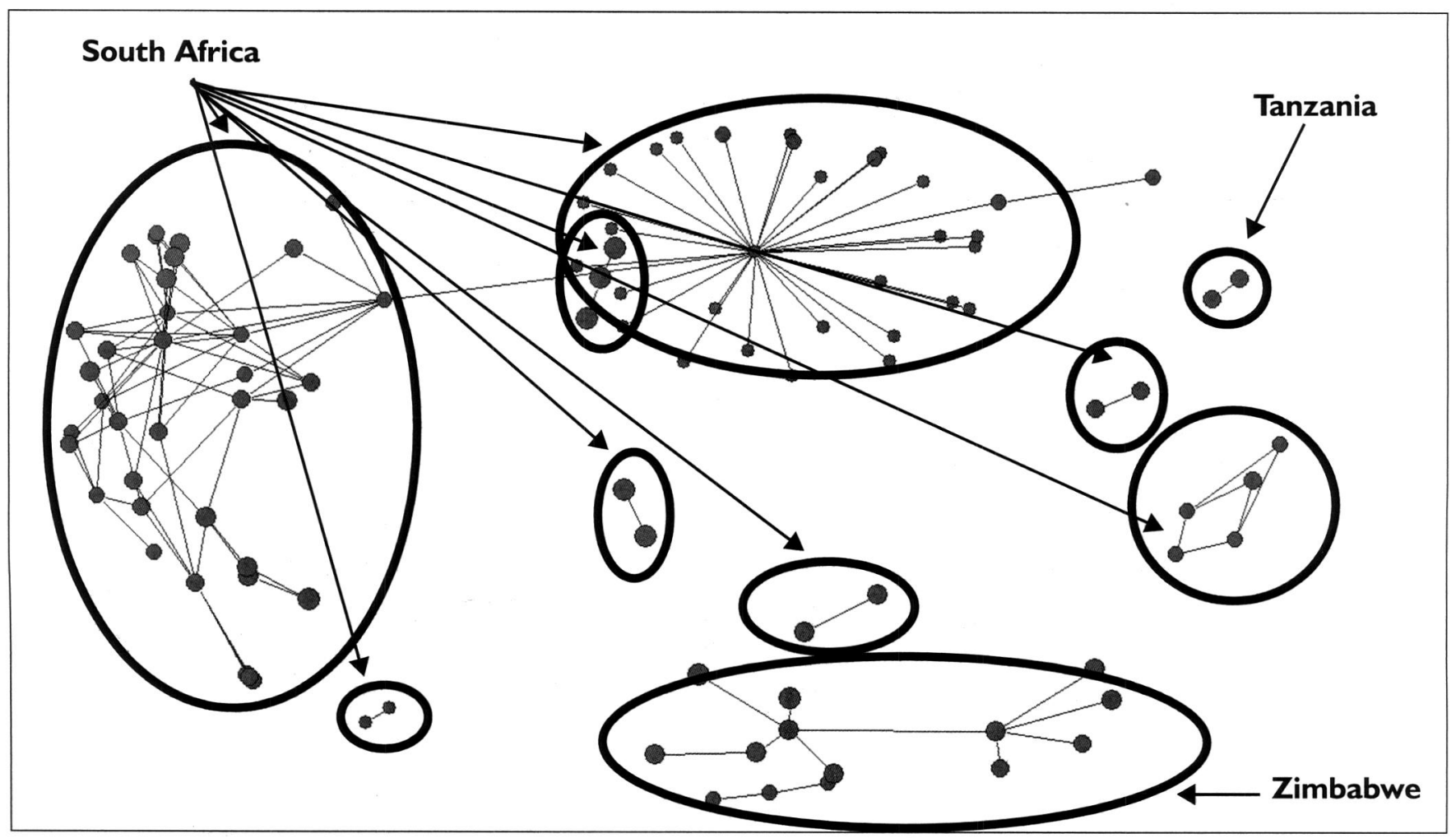

Figure 4 Academic libraries' network map: page in- and out-links 
Fig 2 is a visual presentation of the interlinkages among the libraries using directory in- and out-links. The nature of the directory links was identifiable. Some of the linked directories are concerned with library services, information about the library, information literacy, resources, digital reference library sites, electronic resources, library collections, etc.

Finally, the libraries' web pages network reveals several inter-linkages. Fig 3 and 4 provide a map of the web page linkages with and without labels, respectively. Both illustrations demonstrate dense networks that originated largely from South African academic libraries. There were a total of 8 networks belonging to libraries in South Africa while Tanzania and Zimbabwe produced one network each.

\section{Discussions, conclusions and recommendations}

Notably, libraries in Eastern and Southern Africa are well aware of the benefits and opportunities of the Internet and the Web. Despite the digital divide and technological barriers in the region, librarians in the two regions have expedited the construction of library websites. Out of a total 59 universities in the six countries that had their own websites, only 9 (15.3\%) did not have library websites. Information available from three university websites indicated that the library websites were under construction.

It is our conviction that the location of a link to the library's website on the university's website/home page should be seriously considered when designing the website especially for accessibility purposes. A library whose website is hidden is as good as a library that does not have a website. It was encouraging to note that majority of the libraries' websites had links from the respective universities' main home pages and that these links were well labeled with the term 'library'. To illustrate this more clearly, take for example a library's link that is provided on or under a university's facilities' website. Library users are left to guesswork when accessing such a library's website. Not only does this situation inconvenience a user, but can lead to non-usability of a library's services, resources and products. It was observed in this study that accessibility of three libraries' websites was a bit problematic. Links to these libraries' websites were provided under the 'academics' website. One university provided one page of a description of its library services under the directory heading 'facilities', implying that the library is just as any other facility in the university. Some of the 'other' facilities that were described alongside the library were sports and recreational facilities. It is comforting, though, to note that the university does not have a library website and perhaps that is why the university chose to provide information regarding the library in the way it did. Most probably, when the university library website is constructed, measures will be taken to appropriately provide links at the right place, preferably on the university's home page.

Concerning the provision of essential web-based services, it was noted that the online public access catalogs were the highly regarded service by the libraries most probably because they are valuable tools in accessing a library's collection. Equally seen as essential library services are the guides (or orientation and training resources). Little regard is placed on search engines. Web forms were the least popular. Whereas OPACs and guides are library-specific (i.e. specific to a library offering them), search engines and web forms are not and perhaps that explains why their provision on the libraries' websites is not deemed necessary as they can be accessed through other means. For instance, search engines such as Google can be accessed through its google.com website. However, libraries are advised to provide these services on their websites so as to make it easier for their clients to navigate the Internet from their site. Ahmed (2002:266) observes that "library users value the services that they access from their desktops because the services save time". Concerning the web forms, the author argues that web forms make it easier and convenient for users to communicate to libraries. Communication can be in the form of comments, suggestions, and requests for instruction classes, etc.

The ranking of libraries according to the total number of web pages, out-links and average out-links per page led to the following observations:

- South African university libraries performed better than their counterparts in Botswana, Kenya, Tanzania, Uganda and Zimbabwe

- No university library had a uniform rank throughout the three variables

- Libraries that had branch libraries registered higher number of pages and out-links. For instance, the Howard College Campus library of the University of KwaZulu Natal comprises four libraries, namely, EG Malherbe (Main), Barrie Biermann (Architecture), GMJ Sweeny (Law), and Eleanor Bonnar (Music) while the UCT library consists of the main library and nine branch libraries.

On overall, Rhodes University library was the top ranked followed by Cape Pennisula University library, Stellenbosch University library, KwaZulu Natal (Howard College) libraries, and University of Cape Town libraries. Perhaps librarians from other academic libraries in the region could be advised to learn from the Rhodes University library whose web performance supersedes others.

Similarly, the distribution of the total number of pages, out-links and average out-links per page showed that South Africa was the most prolific country followed by Kenya, Uganda, Botswana, Tanzania and Zimbabwe. Whether this pattern is attributable to technological advancement and/or the availability and implementation of information technology

SA JnI Libs \& Info Sci 2007, 73(I) 
and communication (ICT) policies in the respective countries was not observable from the analyzed data. But recent developments in the formulation of ICT policies in Kenya and South Africa could explain the two countries' performance. There was no information that was readily available regarding the other countries' strategies in the formulation of ICT policies.

The most commonly targeted websites and TLDs include adobe.com, nlm.nih.gov, biblionline.nisc.com, thor.sabinet.co.za, sciencedirect.com, gateway.ovid.com, serialssolutions.com, search.rdsinc.com, home.ncifcrf.gov, scirus.com, etc. Among the 74 top ranked websites and TLDs were online newspapers' sites (e.g. nytimes.com - USA, daily-mail.co.zm - Zambia, sowetan.co.za - South Africa, suntimes.co.za -South Africa, sundaymail.co.zw - Zimbabwe, etc.), electronic databases and database publishers (e.g. nlm.nih.gov, biblionline.nisc.com, sabinet.co.za, sciencedirect.com, isiknowledge.com, etc.), and book- and periodical sellers (e.g. serialssolutions.com, swetsnetnavigator.nl, etc.). This perhaps shows the importance that libraries place on electronically available resources which may have cut down the costs of subscription. Library resources (e.g. journals, magazines, books, reference materials, etc) that used to be only in print format are increasingly becoming available electronically thus changing the libraries' traditional ways of providing such products to their clients. This has called for online subscriptions to journals and other periodicals that were previously accessed through print subscriptions and perhaps the high ranking of electronic databases as the most commonly targeted sites and TLDs explains the changes that libraries are undergoing and have embraced. Accessing these resources, however, requires some computer softwares that are compatible with the formats in which they are published and that may explain adobe.com's popularity among libraries. Most full-text papers are currently published in PDF format.

Figures I, 2, 3, and 4 provide library networks based on site, directory and page in-links and out-links respectively. It was observed that South African academic libraries do have a well developed network that included all the libraries surveyed in this study. Only two libraries each from Tanzania and Zimbabwe formed networks. Contrary to expectations, none of the libraries had links with other libraries outside their geographic regions. The few networks that were generated comprised libraries from the same country. This may imply less collaborative activities between libraries in different countries, although this observation may not be necessarily true since there is "little knowledge about models and motivations of linking" (Zeinolabedinio, Maktabifard \& Osareh, 2006). However, it is well acknowledged that South African libraries do have an established inter-library cooperation and that may explain the inter-linkages that were witnessed among the libraries in the country.

Some libraries were excluded from the analysis on the basis of their website addresses which contained punctuation marks or were too long to be crawled by the personal SOCSCIBOT. Librarians are advised to provide simple and short website addresses of their libraries. Keeping the website address short and clear is very important, especially for purposes of accessibility by users. Library users may want to access the library's website by use of the library's website address and if the address is too long and/or contains some characters/symbols, it may become very difficult to memorize it, thus impeding accessibility. In addition its is recommended that

- Libraries provide space for Open Access repositories which may increase in-links

- Libraries develop useful websites that can attract users and ensure that these websites are always functional

- Libraries develop partnerships with others

- Libraries develop in-house ICT policies which can be entrenched in the main library policy(ies)

Finally, it is recommended that librarians become more involved in the construction of their libraries' websites. They should actively participate in policy formulation as regards legislation of internet-related laws and in the organization of services and resources on the internet. Libraries need to regularly update their websites to keep up with the current proliferation of Internet-based resources that are increasingly becoming freely available. For instance, the current agitation for the availability of journal articles through open access provides opportunities for libraries to improve on link development. Library cooperation (e.g. resource sharing, inter-library loans, etc) needs to be encouraged among academic libraries in Kenya, Tanzania, Uganda and Tanzania so as to improve their web linkages. Further studies are recommended so as:

I.To cover all academic libraries in Sub-Saharan Africa

2.To study the coverage of African academic libraries in major search engines and other online indexing services

3.To use other performance measurements such quality, relevance, etc. in evaluating library websites.

4. To study ICT policies that guide in the construction and maintenance of library websites in Africa

SA JnI Libs \& Info Sci 2007, 73(1) 


\section{References}

Ahmed, S.S. (2002). Managing change to enhance web-based services in the Arabian Gulf libraries. Online Information Review, 26(4): 265-270

Arte, A. (200I). The management of the scientific information environment: the role of the research library web site. Online Information Review, 25(2):88-93

Bar-llan, J. (2005). What do we know about links and linking? A framework for studying links in academic environments. Information processing and Management, 41:973-986

Booth, K. \& Napier, J. (2003). Linking people and information: web site access to National Library of New Zealand information and services. The Electronic Library, 2 I (3):227-233

Clausen, H. (1999). Evaluation of library web sites: the Danish case. The Electronic Library, I7(2): 83-87

Clyde, L.A. (2004). School library web sites: 1996-2002. The Electronic Library, 22(2): I 58-I67

Cordeiro, M.I. \& De Carvalho, J. (2002). Web services: what they are and their importance for libraries. VINE, 32(4):46-62

Covert, K. (200I). How the OCLC CORC service is helping weave libraries into the Web. Online Information Review, 25(I):4I46

Falk, H. (1999). Projecting the library onto the web. The Electronic Library, I7(6):395-399

Falk, H. (2005). State library databases on the Internet. The Electronic Library, 23(4):492-498

Henry, M. (1996). WebCATS. Campus-Wide Information Systems, I3(4): II-I 3

Hildebrand, I. (2002). The South Australian public libraries network web site (iNet): efficiencies through collaboration. Online Information Review, 26(6):375-384

Hundie, K. (2003). Library operations and library resources. The Electronic Library, 2 I (6):555-564

InterLab. 2005. Webometrics ranking of world universities. [Online]. Available http://www.webometrics.info/ (Accessed I0th April 2006)

Kennedy, P. (2004). Dynamic web pages and the library catalogue. The Electronic Library, 22(6):480-486

Kochtanek, T.R., Hein, K.K., Kassim, A.R.C. (200I). A digital library resource web site: Project DL. Online Information Review, 25(I):29-40

McCready, K. (1997). Designing and redesigning: Marquette libraries' web site. Library Hi Tech, no. 59-60:83-89

McKenna, M. (1994). Libraries and the Internet. [Online]. www.ericdigests.org Accessed 27 April 2006

Nielsen, H.J. (2005). New media and new roles of librarianship: illustrated by a literary website of Danish libraries. New Library World, 106(1218/1219):510-518

Pacios, A.R. (2003). Management-related information in Spanish university library web pages. The Electronic Library, 2I (6): 528537

Saeed, H., Asghar, M., Anwar, M. \& Ramzan, M. (2000). Internet use in university libraries of Pakistan. Online Information Review, $24(2): 154-160$

Still, J.M. (200I). A content analysis of university library web sites in English speaking countries. Online Information Review, 25(3): $160-164$

Thelwall, M. 2002a. A comparison of sources of links for academic web impact factor calculations. Journal of Documentation, $58(1): 66-78$

Thelwall, M. 2002b. An initial exploration of the link relationship between UK University Web sites. ASLIB proceedings, $54(2): 118-126$

Thelwall, M. 2002c. Evidence for the existence of geographic trends in university Web site interlinking. Journal of Documentation, 58(5):563-574

Thelwall, M. 2003. Can Google's PageRank be used to find the most important academic web pages? Journal of Documentation, 59(2):205-2I7

Westman, S. (200I). Database-backed library web pages. The Electronic Library, 19(6):424-43I

Xue, S. (2004). Web usage statistics and web site evaluation: a case study of a government publications library web site. Online information Review, 28(3): 180-190

Zeinolabedinio, M. H., Maktabifard, L. \& Osareh, F. (2006). Collaboration analysis of world national library websites via webometric methods. Proceedings on International Workshop on Webometrics, Informetrics and Scientometrics \& Seventh COLLNET Meeting, COLLNET 2006, SRDI-INIST-CNRS-LORIA Nancy, France, 10-12 May 2006. 